Volume 5, Issue SI (2020), pp. 49-54 Journal of School Administration Research and Development ISSN: 2470-8496 Print/ ISSN: 2470-850X Online ojed.org/jsard

\title{
Blinded by the Unknown: A School's Leader's Actions to Support Teachers and Students During COVID-19 School Closures
}

\author{
Laura Schaffer Metcalfe \\ Grand Canyon University, USA \\ Isaac Perez \\ Casa Grande, USA
}

\begin{abstract}
This article outlines a first-hand proactive account of how a school leader directly supported staff, students, and the community to continue learning and growing despite COVID-19 school closures
\end{abstract}

Keywords: families, implications, leadership, low-socioeconomic learners, online learning, pandemic, teachers

COVID-19 had extended its difficulties to an already barriered and low socioeconomic elementary school district destined to push learners in this urban area further behind. An announcement by state-level leaders indicated all schools would close immediately with no opening date available. The purpose of this manuscript is to outline the proactive steps taken by an elementary school principal with the announcement of school closures due to the COVID-19 pandemic. The researchers used a narrative format to gather this information with a focus on the actions taken by the school leader and how he was able to support his teachers, students, families, and school community with continued teaching and learning. 


\section{THE CHALLENGES TO BE UNDERSTOOD (MAIN ARGUMENT)}

There are very few levels of guidance for school leaders when it comes to a worldwide pandemic that lead to school closures. According to Anderson (2020), there was no planning for such a crisis of this significance. However, Professor Jewell-Sherman points out that there is some advice for school leaders in this situation (Anderson, 2020). That advice includes to "forgo top-down decisionmaking, focus on professional development, and sharing best practices through networks", according to Anderson (p.1).

For school leader Isaac Perez, spring break was a time to catch up on tasks and responsibilities that he was not able to address during the busy school year. Then it happened: The state-level elected leadership announced schools would close for the rest of the spring 2020 school year due to the unsafe and unknown nature of COVID-19. Many questions played through Mr. Perez's mind: "How will we provide instruction to learners who are challenged with learning? How do we provide meals to those families who have none? How do we help teachers to pivot to an online learning environment when face-to-face instruction was the norm? How do families without access to electronic devices and Internet connectivity continue their learning?" (I. Perez, personal communication, July 22, 2020).

Immediate communication from the district office was in place to support and guide school leaders of this urban elementary school district, but they were not entirely certain how to lead in this type of an environment due to the new experience. Information indicated that principals, school maintenance workers, and cafeteria workers would be considered essential workers to continue with basic school operations. Teachers, support staff, students, and others would not be reporting to campus after the announcement of school closures. According to Mr. Perez, "I, as a leader, was to report to work on Monday with limited hours along with our maintenance staff and our food service staff" (I. Perez, personal communication, July 22, 2020).

\section{Feeding Families}

According to Mr. Perez, "I initially thought that our schools would be closed for maybe a week or possibly two weeks, until we sorted out the best way to re-enter school" (I. Perez, personal communication, July 22, 2020). Furthermore, Mr. Perez stated, "For the maintenance staff, this team was to disinfect every 
classroom and office space. As a principal, I needed to make sure all lines of communication were open to all our stakeholders." The district communicated via our school and district websites, robotic calls were immediately placed, then communicated via Zoom. The food service manager was planning a food roll out to ensure that the families in the school district had access to nutritious meals throughout the week," he said. Furthermore, Mr. Perez mentioned, "Our district leadership continued to meet periodically which turned into twice-per-week leadership meetings so communication was very clear to all staff members and our stakeholders" (I. Perez, personal communication, July 22, 2020).

Mr. Perez and his essential workers shouldered the food rollouts for his school community to ensure families in this low-socioeconomic area had access to nutritious meals for breakfast and lunch (personal communication, July 22, 2020). He stated, "Food rollouts started daily, where I assisted with handouts to families. I then transitioned to what eventually turned into a twice-per-week food distribution" (I. Perez, personal communication, July 22, 2020).

\section{Next: Digital Learning}

Isaac moved to ensuring that learning for students at his school did not stop. He mentioned, "Electronic learning and communication was the key to reaching our students and their families, since this was the only way we could connect. We crafted a plan to distribute our iPads to our school community" (I. Perez, personal communication, July 22, 2020).

Parents would drive in and pick up the electronic devices. They lined up in alphabetical order and by grade level outside of our multipurpose room. Furthermore, we provided every family with an outline to easily access their online learning (I. Perez, personal communication, July 22, 2020).

Mr. Perez mentioned, "We found out many families did not have Internet service, and many struggled with technology and connectivity with Wi-Fi. We tried to bridge the Internet connectivity gap by providing all families an opportunity to connect with Cox Communications, a local Internet provider" (personal communication, July 22, 2020). Cox communication, in partnership with districts, allowed a discounted rate for those who do not have Internet access. Additionally, we had technology support located at the school and district levels to assist families with set up and other technology-related challenges. We were able to distribute $95 \%$ of our iPads to our students and teachers soon after were able to connect with students. As a principal, I conducted weekly team meetings with teachers and connected into classrooms to view progress (I. Perez, personal communication, July 22, 2020). 


\section{Teacher Training}

We began with teacher online training via Zoom for the first week. Most teachers embraced the idea that we were going to have to teach online, but some were apprehensive to provide instruction via this method. When we started the training for our teachers, our staff camaraderie increased, as teachers were helping each other to connect and helped each other to develop their online instructional skills. Mr. Perez stated, "My teaching staff became creative with making YouTube presentations, video readings which also included our special area teachers of art, physical education, library, and culinary arts, and gardening" (personal communication, July 22, 2020).

For consistency and increased family connections, teachers were required to stay with a schedule to reach families in a relational way. Mr. Perez explained, "We wanted our staff to let families and students know that everything was going to be $\mathrm{OK}$ and we would continue to meet their educational needs. Everyone on our staff was on-board, including our nurse, our secretaries, our social workers, and our school psychologist" (I. Perez, personal communication, July 22, 2020).

\section{ONGOING IMPLICATIONS AND FINAL THOUGHTS}

The most important effort was to connect with every student and to keep every teacher accountable that we were doing our best to provide a quality education online. Mr. Perez pointed out, "We had so many challenges with various students of groups, including our exceptional students and our English learner populations. Meeting the unique needs of every child to ensure they were progressing in their new online education, was exceptionally challenging" (personal communication, July 22, 2020).

We missed our students so much that, according to Mr. Perez, "our teachers coordinated a community parade, as everyone drove through the neighborhood honking our horns while many students and families stood outside and waved as we drove by. One parent wrote on our Facebook page she was so pleasantly surprised that the principal and teachers would do such a kind gesture. In the end, we had a drive through kindergarten promotion and a virtual eighth grade promotion via Zoom which culminated with another drive through celebration. This was a fitting end to our school year and for an unknown future" (I. Perez, personal communication, July 22, 2020). 
Moving forward, this will still be a demanding situation to provide online training for both teachers and students and to make ongoing connections. I am not sure if we are better from this experience, but we can understand and realize what worked and what did not, and to learn from our mistakes (I. Perez, personal communication, July 22, 2020).

Today, this urban elementary school district is still closed for safety reasons and will remain so until health indicators clearly show safe and consistent levels for a return to campus. There were implications for school leaders, as written by Anderson (2020) and mentioned by Harvard Professor Debra Jewell-Sherman. The professor stated that school leaders need to focus on professional development for all teachers to build capacity in a virtual learning environment. Additionally, school leaders should continue to build networks, share best practices about what was working in their schools, and collaborate with other instructional leaders to determine how they were working through the challenges (Anderson, 2020).

\section{REFERENCE}

Anderson, J. (2020, April 16). Harvard EdCastSchool Leadership During Crisis. Harvard Graduate School of Education. https://www.gse.harvard.edu/news/20/04/harvard-edcast-schoolleadership-during-cris:

LAURA SCHAFFER METCALFE, EdD, is an Education Faculty member in the College of Education at Grand Canyon University located in Phoenix, AZ. Her major research interests lie in the area of Title 1 schools and school districts, how teaching and learning can break the cycle of poverty for low-income families and communities, and what the effects of leadership can play in enriching the lives of students and families living and working in lowsocioeconomic areas. Her doctorate and master's degrees are in Educational Leadership from Northern Arizona University. Email: lauram973@gmail.com

ISAAC PEREZ, MEd, is a long-time school leader who holds a Master's degree in Educational Leadership from Northern Arizona University and a Bachelor's degree from Grand Canyon University. Mr. Perez is well-versed and wellexperienced in the ongoing challenges of Title 1 schools with 20 years of experience. Email: isaacp66@gmail.com. 
Manuscript submitted: August 5, 2020

Manuscript revised: September 15, 2020 Accepted for publication: October 5, 2020 